\title{
Industrial competition and earnings quality in Indonesia
}

\section{Dedhy Sulistiawan* and Felizia Arni Rudiawarni}

\author{
Accounting Department, \\ University of Surabaya, \\ Jl. Raya Kalirungkut, Surabaya 60293, \\ East Java, Indonesia \\ Email: dedhy@ubaya.ac.id \\ Email: felizia@staff.ubaya.ac.id \\ *Corresponding author
}

\begin{abstract}
This study examines how the industrial competition affects earnings quality. Our study supports the idea of declining earnings quality when firms' risk increases. We expect that low industrial competition or high market concentration decrease firms' risk by generating more stable revenue for companies. This condition stimulates increasing earnings response coefficient (ERC). Generally, using data from Indonesia, our results show that market concentration affects the relation between earnings surprise and excess return. Further, we find that firms in industries with high market concentration generate higher ERC, especially for profit firms. It means, investors are more likely to use positive earnings data for firms in high market concentration industries in reacting earnings surprise. Our paper contributes to market concentration and ERC studies, especially in Indonesia as one of emerging markets. Low industrial competition improves earnings informativeness.
\end{abstract}

Keywords: market concentration; earnings response coefficient; ERC; industrial competition; Indonesia.

Reference to this paper should be made as follows: Sulistiawan, D. and Rudiawarni, F.A. (2019) 'Industrial competition and earnings quality in Indonesia', Int. J. Economic Policy in Emerging Economies, Vol. 12, No. 2, pp.121-129.

Biographical notes: Dedhy Sulistiawan is an Associate Professor in Accounting at University of Surabaya. His research interest is market-based accounting research and behavioural accounting. He has published books and articles in international journals.

Felizia Arni Rudiawarni is a Lecturer at Accounting Department University of Surabaya. She is interested in financial accounting, especially in earnings management. She also published articles in several international journals.

This paper is a revised and expanded version of a paper entitled 'Market concentration and ERC in Indonesia' presented at SIBR Conference, Seoul, 22-23 February 2018. 


\section{Introduction}

Relevance is the primary quality of financial statement. It indicates the usefulness of accounting information. Since the studies of Ball and Brown (1968) and Beaver (1968), many studies give evidence that earnings information, as one of important information in financial statement, is used by decision makers. Using earnings announcement events, Francis et al. (2002) present financial information is still relevant. If earnings lose its informativeness, investors will use other information for valuation. In that condition, accounting information become useless. This is not the case in Francis et al. (2002) studies. Instead, they find that earnings information released in an announcement is not replaced by competing information, which is analyst recommendation. There are many researches about earnings response coefficient (ERC). Kormendi and Lipe (1987) find a positive relationship between ERCs with earnings persistence. Easton and Zmijewski (1989) and Biddle and Seow (1991) examine ERC relationship and systematic risk. Collins and Kothari (1989) find that in addition to systematic risk, ERC is also associated with growth opportunities. Our study uses market concentration as a determinant factor of ERC. An ERC research in the context of market (or industry) concentration still has a lot of possibilities to be explored. Market (or industry) concentration shows the level of tightness of competition in a market (or industry). The more concentrated the market, the lower the level of market competition and vice versa. Higher market competition generates additional risk by creating uncertainty in revenue stream. On the contrary, lower market competition guarantees more certainty in revenue stream, so investors face lower risk when they invest in stock that are operated in the low competitive market. Since rational investor are assumed to be risk averse, they reduce the risk by selecting low risk firms. Consequently, earnings of firms with lower (higher) risk become more (less) relevance.

In previous research, Biddle and Seow (1991) find a positive relationship between ERC and barriers to entry as a measure of the level of industrial competition. Ahmed (1994) examines the effect of competition, cost structure and growth opportunities on ERC. In essence, Ahmed's finding also supports the research of Biddle and Seow (1991); if the level of competition is higher, than there will be lower revision in the future economic rents. This condition in turn, will lower the change in firm value relative to the change in earnings, hence the lower ERC. Haw et al. (2017) investigate the impact of industry concentration on the future ERC in the international setting. They find that the industry concentration improves the informativeness of stock returns about future earnings. According to Haw et al. (2017) the increasingly higher industry concentration will make it easier for investors to predict future earnings. This finding is also supported by Kama (2009) which states that if the market only consists of two or three large companies (oligopolistic competition) then these companies will be better able to obtain and maintain stable revenue and earnings stream. This condition contributes positively to informativeness of earnings.

Liquid stock market will increase efficiency in capital allocation and provide greater prospects for long-term economic growth (Rahman and Mustafa, 2017). We use Indonesian data, because Indonesia stock market is a thin market with higher risk compare to US market. Assuming risk-adverse investors, earnings informativeness in Indonesia is lower than those in developed market. We try to stimulate ERC by adding information about the level of industry competition. Our result shows that market concentration affect the relation between earnings surprise and excess return, especially 
for profit firms. We find that profit firms in industries with high market concentration generate higher ERC. But for loss firms, market concentration cannot explain the ERC. This result indicates that investors are more likely to use positive earnings data in firms with high market concentration in reacting for earnings surprise. When evaluating market concentration, loss firms are not considered by investors as important information. Conversely, in profit firms, market concentration and earnings are the important determinant of extra return.

Our results contribute to ERC and market concentration studies in Indonesia. We suggest that ERC is affected by market concentration, especially for profit firms. Role of market concentration is crucial in determining the relation between return and earnings surprises. According to Fan and Wong (2002), firms in Indonesia have low earnings informativeness, so by combining information of good news and low industrial competition (high market concentration), can improve the ERC.

This paper is presented as follows. Literature review and hypothesis development are presented in the second section. The third section discusses research design. Result and discussion of this research are presented in the fourth section. The last section concludes.

\section{Literature review and hypothesis development}

The usefullness of accounting information is represented by its relevancy. To evaluate it, many reseachers use ERC, the relation between earnings and stock return. When investors use earnings as their important information, stock return moves into the same direction to earnings. Classical studies of Beaver (1968) and Ball and Brown (1968) are paving the way for research in this field. Dechow et al. (2014) examine researches on the usefulness of accounting earnings. They identify situations in which investors seem to misinterpret earnings information. This situation stimulates security mispricing. Stock price become higher or lower than its fundamental value. Good (bad) news usually produce positive (negative) reaction, but there are different conditions that may produce different magnitude.

Sometimes, prices take more time to fully reflect the information contained within the earnings surprise (Bernard and Thomas, 1989). In different perspective, noise traders tend to ignore other accounting information that identifies temporary distortions in earnings (Sloan, 1996). Those phenomena decrease ERC because of deviation in return-earnings relation. In fact, there are many other factors that affect ERC. Among those are: earnings persistence (Kormendi and Lipe, 1987), systematic risk (Easton and Zmijewski, 1989; Biddle and Seow, 1991), sentiment (Mian and Sankaraguruswamy, 2012), and still many more. This study focuses on market concentration as the main determinant of ERC in Indonesia. The study of ERC in Indonesia, as one of emerging markets, is very important because firms in this country tend to produce low earnings informativeness (Myring, 2006; Fan and Wong, 2002; Landsman et al., 2012).

\subsection{Market concentration}

Market concentration is referred to the level of competition in an industry. We consider that market concentration stimulates risk related to firms' revenue stream. Our idea is supported by some studies. Ahmed (1994) finds that market concentration significantly affects firm's future economic rent, other studies present that market concentration 
affects properties of revenue and earnings streams (Kama, 2009) and valuation of the firm (Thomadakis, 1976; Subrahmanyam and Thomadakis, 1980).

Market share seems to be a more important factor to consider in a concentrated market than in a less concentrated market. The company invests to obtain an increasingly large market share with the aim of gaining the ability to set prices, and other economic factors (Kama, 2009). Therefore, Kama (2009) further expect that market will react more to revenue surprise for firms that operate in the industries that have lower level of competition (in this case is oligopolistic competition). Kama (2009) based this argument by following the idea of Martin (2002) which states that investment capacity hinders the entry of competitors and enable the incumbents to maintain and exercise their market power. In this case, the amount of revenue becomes the representation of capability to continue to exercise market power. In contrast to low-concentration markets, market share differences between firms do not significantly affect profitability (Stigler, 1964; Collins and Preston, 1966). Companies operating in a concentrated market tend to gain a higher profit persistently because of their market power. Strong market power builds entry barriers (Biddle and Seow, 1991). Entry barriers allow companies to enjoy longer economic rent (Strickland and Weiss, 1976; Ahmed, 1994).

\subsection{Market concentration and ERC}

We expect that companies in high market concentration industry enjoy stable earnings stream and benefit from economic rent because of their market power. Therefore, these companies are performing fairly stable and less uncertainty about future earnings. This condition makes investors more able to anticipate the company's earnings in the future (Haw et al., 2017) thus investors use earnings information, and ERC becomes higher.

On the contrary, in high competition or low market concentration, firms have less opportunity to gain above-normal profit and they only enjoy it in the short term, because their rivals can compete them relatively quickly. As a result, firms operating at the level of high market competition (less market concentration) tend to have unstable performance and earnings stream. This condition makes ERC deteriorate.

Concentrated markets are a consequence of the dynamic industry competition (Carter, 1978). From this point of view, firms operating in concentrated markets are efficient firms who are capable of defeating competition and they are the survivors. Therefore, these survivor firms are superior to other firms and they show superior performance in the long run. As a result, these firms have strong market power that they can increase the persistence of their earnings overtime (Lev, 1983) and thus investors are less likely to pay higher information cost to predict future earnings (Haw et al., 2017). We propose the hypothesis:

$\mathrm{H}_{1} \quad$ Higher market concentration stimulate higher ERC.

\section{Research design}

Our study uses data from Indonesian stock market. Indonesia represents one of emerging markets that produce low earnings informativess. To improve the informativeness of earnings, we use industrial competitiveness (market concentration). Our sample consist of 
firms in manufacturing sector from 2011 until 2016. This sector is divided into three sub-sectors, those are basic industry, miscellaneous industry and consumer goods industry. In measuring market concentration between sub-sectors, we use Herfindahl-Hirschman Index (HHI). The higher HHI, the higher market concentration, means the lower industrial competition among firms in that industry. To test the hypothesis, our regression model examines the association between market concentration and ERC. The model is presented as follows.

$$
\begin{aligned}
E R_{t}= & \alpha+\beta_{1} E P S_{t}+\beta_{2} \Delta E P S_{t}+\beta_{3} H H I_{t}+\beta_{4} \Delta E P S_{t} x H H I_{t} \\
& +\beta_{5} L n A_{t-1}+\beta_{6} D A R_{t-1}+\varepsilon_{t}
\end{aligned}
$$

ER excess return (return of firm $i$ deducted by market return)

EPS earnings per share

$\triangle E P S \quad$ earning surprise $\left(E P S_{t}-E P S_{t-1}\right)$

HHI market concentration, which is the sum of the squared market shares of the firms competing in each industry sub-sector

LnTA size of the firm (logarithm natural of total asset)

$D A R \quad$ debt to total assets

$t \quad$ Period.

Higher market concentration or lower market competition is expected to produce stronger ERC. We expect that the coefficient of $\beta_{4}$ will be positively significant. We believe that $\mathrm{HHI}$ is the moderating variable of $\triangle \mathrm{EPS}$ and ER, it improves ERC because higher HHI sample tend to generate more stable earnings. Risk-adverse investors prefer lower deviation of earnings to minimise their risk in estimating future cash flow.

There are 772 firms-year for six years observation periods. We trim data with extreme value, so we have 720 firms-year observation. Table 1 describes descriptive statistics of the variables that are presented in minimum, maximum, mean and standard deviation values. In determining market concentration, our study uses HHI index that is composed based on its sub sectors. After calculating HHI index, we find that miscellaneous industry (basic industry) has the highest (lowest) market concentration index during six years of observation. Consumer goods industry is in medium-market competition.

Table 1 Descriptive statistics

\begin{tabular}{lcccc}
\hline Variable & Minimum & Maximum & Mean & Std. deviation \\
\hline$E R_{t}$ & -1.0274 & 2.0155 & -0.029852 & 0.4021101 \\
EPS $_{t}$ & $-17,350.3869$ & $169,954.0854$ & $1,149.623013$ & $9,698.3774172$ \\
$\Delta E P S_{t}$ & $-121,977.2891$ & $122,375.8097$ & 118.709565 & $6,916.9016489$ \\
$H H I_{t}$ & 0.0522 & 0.5740 & 0.191505 & 0.1707934 \\
nn_TA $_{t-1}$ & 24.5345 & 33.1341 & 28.169470 & 1.5734566 \\
$D A R_{t-1}$ & 0.0163 & 4.9803 & 0.545761 & 0.4736264 \\
\hline
\end{tabular}




\section{Results}

Table 2 shows the regression results of the relationship between market concentration and ERC for full sample, profit firms and loss firms. It appears that the result for full sample and profit firms provides almost the same results, because the observations are dominated by profit firms. The test shows that earnings surprise ( $\triangle \mathrm{EPS}$ ) has a negative effect on excess returns. These findings indicate that investors dislike risk, whereas they prefer more stable and predictable earnings streams. From the test we see that market concentration (HHI) alone is not able to influence the excess return. However, market concentration has a significant effect on the relationship between earnings surprise and excess returns. This can be seen from the coefficient of $\triangle E P S H H I$ which has a significant positive effect on excess return. For companies operating in high market concentration (low competition level), investors feel more secure because even though the company experiences large earnings changes, the companies in the low competition industry have more stable earnings streams. This test results support $\mathrm{H} 1$.

Table 2 Market concentration and ERC

\begin{tabular}{|c|c|c|c|c|c|c|}
\hline \multirow{2}{*}{ Variable } & \multicolumn{2}{|c|}{ Full sample } & \multicolumn{2}{|c|}{ Profit firms } & \multicolumn{2}{|c|}{ Loss firms } \\
\hline & Coeff. & t-value & Coeff. & t-value & Coeff. & $t$-value \\
\hline Constant & -0.0312 & -0.1179 & -0.0444 & -0.1506 & 0.4590 & 0.8125 \\
\hline$E P S_{t}$ & 0.0000 & 0.4066 & 0.0000 & 0.2291 & 0.0000 & 0.5053 \\
\hline$\Delta E P S_{t}$ & -0.0001 & $-6.5193 * * *$ & -0.0001 & $-6.1752 * * *$ & -0.0001 & -0.8010 \\
\hline$H H I_{t}$ & -0.0363 & -0.4141 & -0.0697 & -0.6819 & 0.1246 & 0.7694 \\
\hline$\Delta E P S H H I_{t}$ & 0.0004 & $7.0067 * * *$ & 0.0004 & $6.6092 * * *$ & 0.0004 & 1.0917 \\
\hline$L n \_T A_{t-1}$ & 0.0011 & 0.1163 & 0.0016 & 0.1563 & -0.0224 & -1.1111 \\
\hline$D A R_{t-1}$ & -0.0419 & -1.3184 & 0.0301 & 0.6155 & -0.0367 & -0.9470 \\
\hline F-test & $8.4753 * * *$ & & $7.6126^{* * *}$ & & 0.5328 & \\
\hline Adj. $\mathrm{R}^{2}$ & 0.0588 & & 0.0641 & & -0.0207 & \\
\hline
\end{tabular}

Notes: Dependent variable: excess return.

$*, * *, * * *$ significant at $10 \%, 5 \%$ and $1 \%$ respectively.

To improve the analysis of the results, we separate the sample based on profit and loss firms (see Table 2 because profit or loss information stimulate different behaviour (Collins et al., 1999; Swanson et al., 2003). Profit firms usually contain more information than loss firms. Using loss firms, the model is not statistically fit. Using profit firms sample, we find that market concentration has a significant positive effect on ERC, the same as full sample result. $\triangle E P S H H I_{t}$ affects excess return and it is significant at $1 \%$. Our test finds that profit firms in industries with high market concentration generate higher ERC. Specifically, investors are more likely to use positive earnings data for firms in low industrial competition (high market concentration) in reacting to earnings surprise. In industry with low competition (high market concentration), negative profit may provide no information for future earnings stream and investors shift their attention from earnings to other information. Firms in low industrial competition (or high market concentration) usually have stable earnings stream. These earnings are used to estimate future cash flow of the firms. In a high market concentration, analysts' prediction for profit firms are easier to use rather than the loss ones. Many valuation books 
(Damodaran, 2006; Subramanyam and Wild, 2013) already state this situation. In valuing firms, generally, investors or analysts assume positive earnings rather than negative one. Our findings not only contribute to market concentration and ERC studies but also to asymmetric reaction literatures. In evaluating stock returns, investors tend to put more emphasis to profit firms to analyse the relationship between earnings and market concentration than to loss firms.

\section{Conclusions}

Accounting communities state that relevancy of accounting information is the primary quality of financial statement. Our study focusses on ERC as one of proxies in measuring relevancy. Overall, we provide evidence that market enhance the informativeness of earnings, especially for profit firms. Grouping sample between profit and loss firms is very important because investors or analysts shift their focus from earnings to other indicators in predicting future cash flows when companies suffered severe losses.

Complementing Haw et al. (2017), our finding contributes to ERC studies, especially on determining market concentration to ERC in emerging markets. The second contribution is provided by showing different impact of market concentration to ERC for profit and loss firms. Based on those results, future studies can use earnings component to evaluate detail impact of market concentration to ERC. Future studies may also consider the role of corporate governance because nowadays stakeholders tend to put a pressure on this. Product and quality are not the only factors considered in the competition, but also brand and the reputation of the company take into account (Golja and Paulisic, 2010). One of the most corporate governance mechanisms that are broadly studied is board characteristics because this factor can affect earnings quality (Amin et al., 2018). Since industrial competition cannot be separated from the role of macro factors in a country, we propose to consider these factors for future research, for example foreign direct investment (FDI). According to Handoyo and Budiharta (2015), in the era of globalisation, FDI plays an important role. FDI will increase domestic capital and open access for transfer of new technology (Abu Bakar and Afolabi, 2017). This, in turn, will change the level of industrial competition and their effects to stock returns.

\section{References}

Abu Bakar, N. and Afolabi, L. (2017) 'Causal nexus between trade, political instability, FDI and economic growth: Nigeria evidence', International Journal of Trade and Global Market, Vol. 10, No. 1, pp.75-82.

Ahmed, A.S. (1994) 'Accounting earnings and future economic rents: an empirical analysis', Journal of Accounting and Economics, Vol. 17, No. 3, pp.377-400.

Amin, A., Lukviarman, N., Suhardjanto, D. and Setiany, E. (2018) 'Audit committee characteristics and audit-earnings quality: empirical evidence of the company with concentrated ownership', Review of Integrative Business and Economics Research, Vol. 7, No. Supplementary 1, pp.18-33.

Ball, R. and Brown, P. (1968) 'An empirical evaluation of accounting income numbers', Journal of Accounting Research, Autumn, Vol. 6, No. 2, pp.159-178.

Beaver, W.H. (1968) 'The information content of annual earnings announcements', Journal of Accounting Research, Vol. 6, pp.67-92, Empirical Research in Accounting: Selected Studies. 
Bernard, V.L. and Thomas, J.K. (1989) 'Post-earnings-announcement drift: delayed price response or risk premium?', Journal of Accounting Research, Vol. 27, pp.1-36, Current Studies on The Information Content of Accounting Earnings.

Biddle, G.C. and Seow, G.S. (1991) 'The estimation and determinants of associations between returns and earnings: evidence from cross-industry comparisons', Journal of Accounting, Auditing \& Finance, Vol. 6, No. 2, pp.183-232.

Carter, J.R. (1978) 'Collusion, efficiency, and antitrust', The Journal of Law and Economics, Vol. 21, No. 2, pp.435-444.

Collins, D.W. and Kothari, S.P. (1989) 'An analysis of intertemporal and cross-sectional determinants of earnings response coefficients', Journal of Accounting and Economics, Vol. 11, Nos. 2-3, pp.143-181.

Collins, D.W., Pincus, M. and Xie, H. (1999) 'Equity valuation and negative earnings: the role of book value of equity', The Accounting Review, Vol. 74, No. 1, pp.29-61.

Collins, N.R. and Preston, L.E. (1966) 'Concentration and price-cost margins in food manufacturing industries', The Journal of Industrial Economics, June, Vol. 14, No. 3, pp.226-242.

Damodaran, A. (2006) Damodaran on Valuation: Security Analysis for Investment and Corporate Finance, 2nd ed., John Wiley \& Sons, Hoboken, New Jersey.

Dechow, P.M., Sloan, R.G. and Zha, J. (2014) 'Stock prices and earnings: a history of research', Annu. Rev. Financ. Econ., Vol. 6, No. 1, pp.343-363.

Easton, P.D. and Zmijewski, M.E. (1989) 'Cross-sectional variation in the stock market response to accounting earnings announcements', Journal of Accounting and Economics, Vol. 11, Nos. 2-3, pp.117-141.

Fan, J.P. and Wong, T.J. (2002) 'Corporate ownership structure and the informativeness of accounting earnings in East Asia', Journal of Accounting and Economics, Vol. 33, No. 3, pp.401-425.

Francis, J., Schipper, K. and Vincent, L. (2002) 'Earnings announcements and competing information', Journal of Accounting and Economics, Vol. 33, No. 3, pp.313-342.

Golja, T. and Paulisic, M. (2010) 'Corporate governance, social responsibility and corporate reputation: an empirical analysis of the situation in Croatia', Int. J. of Economic Policy in Emerging Economies, Vol. 3, No. 4, pp.368-384.

Handoyo, B.Y. and Budiharta, P. (2015) 'The effect of IAS 32 and IAS 39 adoptions on earnings quality: a study of banking companies in Indonesia', Review of Integrative Business and Economics Research, Vol. 4, No. 1, pp.397-409.

Haw, I.M., Hu, B., Lee, J.J. and Wu, W. (2016) 'The impact of industry concentration on the market's ability to anticipate future earnings: international evidence', International Journal of Accounting \& Information Management, Vol. 24, No. 4, pp.443-475.

Kama, I. (2009) 'On the market reaction to revenue and earnings surprises', Journal of Business Finance \& Accounting, Vol. 36, Nos. 1-2, pp.31-50.

Kormendi, R. and Lipe, R. (1987) 'Earnings innovations, earnings persistence, and stock returns', Journal of Business, July, Vol. 60, No. 3, pp.323-345.

Landsman, W.R., Maydew, E.L. and Thornock, J.R. (2012) 'The information content of annual earnings announcements and mandatory adoption of IFRS', Journal of Accounting and Economics, Vol. 53, Nos. 1-2, pp.34-54.

Lev, B. (1983) 'Some economic determinants of time-series properties of earnings', Journal of Accounting and Economics, Vol. 5, pp.31-48.

Martin, S. (2002) Advanced Industrial Economics, 2nd ed., Blackwell Publishing, Oxford, USA.

Mian, G.M. and Sankaraguruswamy, S. (2012) 'Investor sentiment and stock market response to earnings news', The Accounting Review, Vol. 87, No. 4, pp.1357-1384. 
Myring, M. (2006) 'The relationship between returns and unexpected earnings: a global analysis by accounting regimes', Journal of International Accounting, Auditing and Taxation, Vol. 15, No. 1, pp.92-108.

Rahman, M. and Mustafa, M. (2017) 'Financial deepening and stock market returns: panel data analyses for selected developed and developing economies', International Journal of Monetary Economics and Finance, Vol. 10, No. 1, pp.96-109.

Sloan, R.G. (1996) 'Do stock prices fully reflect information in accruals and cash flows about future earnings?', The Accounting Review, Vol. 7, No. 3, pp.289-315.

Stigler, G.J. (1964) 'A theory of oligopoly', Journal of Political Economy, Vol. 72, No. 1, pp.4461.

Strickland, A.D. and Weiss, L.W. (1976) 'Advertising, concentration, and price-cost margins', Journal of Political Economy, Vol. 84, No. 5, pp.1109-1121.

Subrahmanyam, M.G. and Thomadakis, S.B. (1980) 'Systematic risk and the theory of the firm', The Quarterly Journal of Economics, Vol. 94, No. 3, pp.437-451.

Subramanyam, K.R. and Wild, J.J. (2013) Financial Statement Analysis, 12th ed., McGraw-Hill, New York.

Swanson, E.P., Rees, L. and Juarez-Valdes, L.F. (2003) 'The contribution of fundamental analysis after a currency devaluation', The Accounting Review, Vol. 78, No. 3, pp.875-902.

Thomadakis, S.B. (1976) 'A model of market power, valuation and the firm's returns', The Bell Journal of Economics, Spring, Vol. 7, No. 1, pp.150-162. 
International Journal of

Economic Policy in Emerging Economies 


\section{International}

\section{Journal of}

\section{Economic Policy}

\section{in Emerging}

\section{Economies}

Volume 12, No. 2, 2019

Publisher's website: www.inderscience.com

Email: editorial@inderscienr.e.com

ISSN (Print) 1752-0452

ISSN (Online) 1752-0460

Copyright@ 2019 Inderscience Enterprises Ltd

No part of this publication may be reproduced stored or transmitted in any material form or by any means (including electronic, mechanical, photocopying, recording or otherwise) without the prior written permission of the publisher, except in accordance 'vith the provisions of the Copyright Designs and Patents Act 1988 or under the terms of a licence issued by the Copyright Licensing Agency Ltd or the Copyright Clearance Center Inc.

Published and typeset in the UK by Inderscience Enterprises Ltd 


\section{Contents}

\section{SPECIAL ISSUE: FINANCE-GROWTH NEXUS AND SUPPORTING POLICIES IN EMERGING ECONOMIES}

Guest Editor: Dr. Arnold C.S. Cheng

$101 \quad$ Editorial

Arnold C.S. Cheng

103 Trade realignment position in ECOWAS with gravity model Nnanna P. Azu

113 Working capital management and its impacts on profitability: the case of small and medium food enterprises in Nakhon Ratchasima, Thailand Sareeya Wichitsathian

121 Industrial competition and earnings quality in Indonesia Dedhy Sulistiawan and Felizia Arni Rudiawarni

130 Financial strategy of small and medium businesses on the creative industry in Bandung, Indonesia

Nenden Kostini and Sam 'un Jaja Raharja

140 Competitive analysis of public urban transport

Ekaterina Ogorodnikova, Alexander Sidorenko anä Andrey Plakhin

149 Scale economies in the Korean airline industry since the entry of low-cost carriers

Sang-Lyul Ryu and Javoun Won

158 Analyses on the determinants of elderly workers' plans to retire and desired retirement age

Moon-Hee Shin and Young-Min Lee

166 Does bureaucracy lead to economic development in ASEAN? Mohamad Khusaini

175 Domination among tour operators in Karst conservation area of Goa Pindul, Indonesia

Victoria Sundari Handoko

182 Place branding as Bandung City's competitive advantage Pratami Wulan Tresna, Arianis Chan and Mohammad Benny Alexand i

190 Integrated media for public relations of promoting a local product to global markets: a case analysis on Thai food

Cherdpong Kheerajit, Sarinya Paisarnsombat and Narong Sompong

i98 Does online social presence lead to purchase intentions? Muddasar Ghani Khwaja, Ahmad Jusoh and Khalil Md Nor 


\section{Contents}

207 The impact of relationship marketing on customer value, satisfaction and ioyalty: evidence from banking sector in Indonesia Ludfi Djajanto, Yunia Afiatin and Zainal Abchl Haris

215 The erfects of skills and challenges, perceived risk, and flow experience on experience value and satisfaction - a study on adventure recreation in Taiwan

Wen-Cheng Chu, Cedric Hsi-Jui Wu, Chen-Hsiung Chou, Yi-Ting Chu, $Y_{l}$-Chi Chu and Shu-Hui Chang 


\title{
International Journal of Economic Policy in Emerging Economies (IJEPEE)
}

\section{Editor}

Professor Bruno S. Sergi

University of Messina, Department of Economics, Via dei Verdi, 75, 98122 Messina. Italy

Email: bsergi@unime.it

\section{Managing Editor}

Dr. Irwan Trinugroho

Universitas Sebelas Maret (UNS), Department of Management

Faculty of Economics and Business, Jl. Ir. Sutami 36A,

Kentingan, Surakarta 57126, Indonesia

Email: irwan.trinugroho@gmail.com

\author{
Associate Editors \\ Associate Professor Svetlana Balashova \\ Peoples' Friendship University of Russia (RUDN University), Mathematical Modelling in \\ Economics, 6, Miklukho-Maklaya, Moscow 117198, Russia \\ Email: balashova_sa@pfur.ru \\ Professor Natalia Volgina \\ Peoples' Friendship University of Russia (RUDN University), International Economic Relations \\ 6, Miklukho-Maklaya, Moscow 117198, Russia \\ Email: volgina_na@pfur.ru
}

\section{Members of the Editorial Board}

Professor Wladimir Andreff

Professor of Economics

Université Paris 1 Pantheon Sorbonne

Maison des Science Economiques

106-112 boulevard de l'Hôpital

75647 Paris Cadex 13, France

Email: andreff@club-internet.fr

Dr. Antoni Chawluk

Fellow and Tutor in Economics

University of Oxford

Mansfield Coliege

Mansfield Rd., Oxford OX1 3TF, UK

Email: antoni.chawluk@mansfield.ox.ac.uk

Professor Tatiana Chetvernina

Director of the Institute for Social

Development Studies, State University

Higher School of Economics

Myasnitskaya str., 20-407, 101000

Moscow, Russia

Email: tchetver@yahoo.com; tchetvernina@hse.ru

Professor Dr. Anthony S. Courakis Brasenose College, University of Oxford and Greek Ambassador, Permanent Representative to the OECD

Permanent Delegation of Greece to the OECD, 15 , Villa Saîd, 75116 Paris France

Email: anthony.courakis@economics.ox.ac.uk
Professor Fernando J. Fuentes García Vice-Dean, University of Córdoba Faculty of Law, Economy and Business Administration C Puerta Nueva s/n 14071 Córdoba, Spain Email: Fernando.fuentes@uco.es

\section{Dr. Bela Galgoczi}

Senior Economist

European Trade Union Institute

Bculevard du Roi Albert II 5

B-1210 Brussels, Belgium

Email: bgalgoczi@etui-rehs.org

Stcke-on-Trent

Staffordshire, ST4 2DF, UK

Email: i.hashi $a$ staffs.ac.uk

Professor Dr. Per Högselius Director of Studies

Lund University, CIRCLE

P.O. Box 117, Stora Algatan 4

SE-22100 Lund, Swecien

Email: per.hogselius a circle.lu.se

Professor András Inotai

General Director

Institute for World Economics

Hungarian Academy of Sciences

Orszaghaz เ.. 30

i014 Budapest. Hungary

Email: andrasinotai@yahoo.com 
Members of the Editorial Board (continued)

Professor Tationa M. Isachenko Vice-Dean, School of International Business and Business Administration Moscow State Institute of International Relations (MGIMO)

Department of international Economic Relations, 76 Vernadsky Av. 119454 Moscow, Russian Federation Email: isachenko $a$ mgimo.ru

Professor Khalifa Hmood Jaber

Al Falah University

United Arwis Emirates

Email: coba $a$ aiu.ac.ae

\section{Dr. David Kernohan}

Head of Economics and Statistics

Middlesex University Business School

The Burroughs, Hendon London

NW4 4BT, UK

Email: D.Kernohan amdx.ac.uk

Professor Michele Limosani

University of Messina

DESMaS "V. Pareto"

Faculty of Political Science

Via T. Cannizzaro, 278

I - 98122 :Messina, Italy

Email: limosani@unıme.it

Professor Sushanta Mallick

School of Business and Management Queen Mary. University of Lendon

Mile End Road, London E1 4NS, UK

Email: s.k.mallick@qmul.ac.uk

Professor Roman Matousek

Nottingham University, UK

Email: roman.matousek@nottingham.ac.uk

\section{Professor Pietro Navarra}

University of Messina

DESMaS "V. Pareto"

Faculty of Economics

I - 98122 Messina, Italy

Fmail: pietro,navarra $x$ unime it

\section{Professor Patrick O'Sullivan}

Head of Department of People

Organisations and Society

Grenoble Ecole de Management

12 Rue Pierre Sémard

38003 Grenoble, France

Email: patrick.osullivan $a$ grenoble-cm.com

\section{Professor Dr. Goran Petrevski}

Ss. Cyril and Methodius University Faculty of Economics, Krste Misirkov Blvd. 1000 Skopje, Macedonia

Emaii: goran@eccf.ukim.edu.mk

Professor Elena Popkova

Volgograd State Technical University,

28 Lenina Avenue,

Volgograd, 400131

Russian Federation

Email:210471@mail.ru

Professor W. Charles Sawyer

Professor of Economics, Department of

Economics, Texas Christian University

TCU Box 298510

Fort Worth, TX 76129, USA

Email:w.c.sawyer@tcu.edu

Dr. Werner Sengenberger

Former Director, Employment Strategy

Department, ILO; Consultant

7 Les Collines de Pitegny

385 Chemin de l'Ovellas

F-01170 Gex, France

Email: sengenberger.w@wanadoo.fr

Professor Željko Šević

School Dean

Universiti Utara Malaysia

Othman Yeop Abdullah

Graduate School of Business

06010 Sintok, Kedah Darul Aman, Malaysia

Email: z.sevic@uum.edu.my

\section{Professor Emiliano Sironi}

Catholic University of the Sacred Heart - Milan

Department of Statistival Sciences

Large Geme!li, 1

20123 Milano, Italy

Email: emiliaro.sironi@unicatt.it

Professor Khaled Soufani

University of Cambridge

Judge Business School

Trumpington St.

Cambridge CB2 1AG, UK

Email: k.soufani@jbs.cam.ac.uk

Professor Stefan Stefanov

Dept. of Economics

New Bulgarian University,

Sofia, Bulgaria.

Email: sstefanov@nbu.bg 
Members of the Editorial Board (continued)

\section{Dr. Pekka Sutela}

Director, Institute for Economies in Transition (BOFIT), Bank of Finland, PO Box 160

Fin-00101 Helsinki, Finland

Email: pekka.sutela@bof.fi

Dr. Vladimir Tikhomirov

Senior Economist

UralSib Finance Corporation

8 Efremova Street

Moscow 119048, Russian Federation

Email: tih_vi@uralsib.ru

Dr. Evgeny Vinokurov

Head of Economic Analysis Unit

Eurasian Development Bank

Strategy and Research Department

Abdullinykh Str. 56

Aimaty 050000, Kazakhstan

Email: Vinokurov_EY@eabr.org
Professur Ingo Waiter

Seymour Milstein Professor o: Finance, Corporate Governance and Ethics

New York University

Stern School of Business

44 West 4 th Street

New York, NY 10012, LSA

Email: iwalter@stern.nyu.edu

\section{Dr. Andrei Yakovlev}

State University - Higher School of

Economics

Institute for Industrial and

Market Studies 20, Myasnitskaya

101987 Moscow. Russian Federation

Email: ayakovlev@hse.ru 